\title{
Women For Oncology
}

\author{
Jyoti Bajpai ${ }^{1}$ \\ ${ }^{1}$ Tata Memorial Centre, Homi Bhabha National Institute, Mumbai, \\ Maharashtra, India \\ Ind J Med Paediatr Oncol 2022;43:3.
}

"He" is "skilful" if successful however, "She" is only "lucky" .... may not be the truth but certainly a Societal Perception!

Dear friends, I am truly humbled and overwhelmed to write this message at the release of this very special themed issue titled "Women for oncology (W4O)" - a topic too close to my heart (and soul and mind) and rather it is not a topic but ingrained in my life.

The fairer sex constitutes the better half of the world's population and are making great strides all across; however, women often face a conscious or subconscious gender bias, at all stages of their career and growth in every field including medicine. I have seen brilliant and hard-working women in science facing discrimination due to stereotyping, lack of opportunities for leadership roles and need to validate themselves repeatedly in a men-dominating world.

This is objectively proven by large surveys conducted world over and in India that women are underrepresented in academia as leaders or lead authors in journals. Their ambitions are more often called "aggressive." Gender issue is not a woman issue but it is a human issue-we all are affected by this and there cannot be any sustainable development without gender equality. Efforts are in place internationally (e.g., European Society of Medical Oncology [ESMO] W4O) and in India (W4O-India) toward establishing gender equality; however, we have miles to go.
Address for correspondence Jyoti Bajpai, MD, DM, Tata Memorial Centre, Homi Bhabha National Institute, Mumbai, Maharashtra 400012, India (e-mail: dr_jyotibajpa@@yahoo.co.in; drjyotibajpai25@gmail.com).

The current issue is a small step toward this far off goal; however, since each drop counts in an ocean, this step may help in decreasing this large gender gap or at least sensitize the community toward the burning issue! Here we are providing the women in science and medicine a unique opportunity wherein all the lead authors and editorial board members are women.

Let me tell you, women need supporting, open-minded men to join hands and collaborate to keep this momentum on and I wish to keep this on record that I am whole heartedly supported by my friend Dr. Padmaj Kulkarni in this effort. I am thankful to other colleagues and editorial board members who again were very positive about this thought and guest women editors who supported me in this endeavor.

I am grateful to the women leaders who came forward to support this effort and submitted their precious hard work toward our journal including the ESMO leaders, the visionary woman president Dr. Solange Peters, and W4O chair Dr. Pilar Garrido despite the ongoing coronavirus disease 2019 pandemic.

I will stop my pen here and please remember,

"Life (as a woman oncologist) may not be a party we may hope for, but while we are here, we should dance (with full heart and soul and mind)"

Happy reading!
DOI https://doi.org/ 10.1055/s-0042-1743181. ISSN 0971-5851. (c) 2022. Indian Society of Medical and Paediatric Oncology. All rights reserved.

This is an open access article published by Thieme under the terms of the Creative Commons Attribution-NonDerivative-NonCommercial-License, permitting copying and reproduction so long as the original work is given appropriate credit. Contents may not be used for commercial purposes, or adapted, remixed, transformed or built upon. (https://creativecommons.org/ licenses/by-nc-nd/4.0/)

Thieme Medical and Scientific Publishers Pvt. Ltd., A-12, 2nd Floor, Sector 2, Noida-201301 UP, India 